Citation: Castillo-Arias, E. A García-López, E., Palma-López, D. J., Alejandro-Magaña, M., HernándezSánchez, G., \& Obrador-Olán, J. J. (2021). Characterization of black mangrove (Avicennia germinans) and red mangrove (Rhizophora mangle) ecosystems in Paraíso, Tabasco, Mexico. Agro Productividad. https://doi. org/10.32854/agrop.v14i12.1983

Editor in Chief: Dr. Jorge Cadena Iñiguez

Received: March 22, 2021. Accepted: November 14, 2021. Published on-line: December 30, 2021 .

Agro Productividad, 14(12). December. 2021. pp: 83-90.

This work is licensed under a Creative Commons Attribution-NonCommercial 4.0 International license.

\section{Characterization of black mangrove (Avicennia germinans) and red mangrove (Rhizophora mangle) ecosystems in Paraíso, Tabasco, Mexico}

\author{
Castillo-Arias, Edith A. ${ }^{1}$; García-López, Eustolia ${ }^{1}$; Palma-López, David J. ${ }^{1}$; \\ Alejandro-Magaña, Miguel ${ }^{2}$; Hernández-Sánchez, Gerardo ${ }^{1}$ Obrador-Olán, José J. ${ }^{1^{*}}$ \\ 1 Colegio de Postgraduados Campus Tabasco, Cárdenas, Tabasco, México, C. P. 86500. \\ 2 Universidad Juárez Autónoma de Tabasco, Centro, Tabasco, México, C. P. 86150. \\ * Correspondence: obradoro@colpos.mx
}

\begin{abstract}
Objective: To characterize black and red mangrove ecosystems in the coastal zone of Paraíso, Tabasco, Mexico.

Design/Methodology/Approach: Four plots were randomly established in each mangrove ecosystem. Inside each plot, trees were counted per transect, and measured for basal area, diameter at breast height, plant cover and height. Seven diametric classes were estimated to calculate the relative species richness and the dynamics of emergence/disappearance in the ecosystem. Soil samples were surveyed at two depths and during different seasons (dry and rainy). The samples were tested for organic matter $(\mathrm{OM})$, nitrogen content $(\mathrm{N})$, phosphorus (Olsen P), pH, exchangeable bases and humic and fulvic acids; with the objective to characterize nutrient flux dynamics between seasons and compare the two mangrove ecosystems.

Results: Red mangrove ecosystems contain higher OM during rainy season. Black mangrove ecosystems showed low contents of $\mathrm{OM}$ and exchangeable bases during dry season. The species with more individuals $\mathrm{m}^{-2}$ is red mangrove, and black mangrove presents individuals with greater basal area and diameters.

Study Limitations/Implications: Regional characterization of mangrove ecosystems provides information about nutrient flux, which is necessary for the adequate proposal of protection and conservation programs of these wetlands.

Findings/Conclusions: The dominant mangrove species affects nutrient flux in soils associated to the ecosystem, suggesting they have specific functions in the ecosystem dynamics.
\end{abstract}

Keywords: Wetlands; coastal ecosystems; organic matter; nutrients flux; forestry richness.

\section{INTRODUCTION}

Mangroves are coastal wetland ecosystems that occupy a privileged place because of their natural wealth and the environmental services they provide, in addition to representing an important ecological role that has been recognized internationally. They are valuable natural ecosystems that face severe alterations, such as contamination from the discharge of 
residual waters and the overexploitation of products derived from these, which affect their structure, functioning and their very existence (Domínguez-Domínguez et al., 2011). In Mexico there are five species of mangrove: Rhizophora mangle L. (red mangrove), Avicennia germinans L. (black mangrove or dark mangrove), Laguncularia recemosa L. (white mangrove), Conocarpus erectus L. (botoncillo mangrove) and Rhizophora harrisonnii (caballero mangrove) (Corella-Justavino et al., 2004; Domínguez-Domínguez et al., 201 1). All of them are found in the category of special protection NOM-ECOL-059/2001 (SEMARNAT, 2002). The state of Tabasco has $189 \mathrm{~km}$ of coast, where coastal lagoon systems are located, among which there are $40 \mathrm{~km}^{2}$ of mangrove forests (Pérez-Sánchez et al., 2002; ValderramaLanderos et al., 2017).

The mangroves in the municipality of Paraíso, Tabasco, have special importance for rural communities, not only as traditional forest resource; currently their importance is centered in various ecosystem services that they provide to improve the quality of life of nearby populations (Sánchez et al., 2016). Understanding the characteristics of the mangrove ecosystems in the coast of Paraíso, Tabasco, could be the basis for the characterization and identification of the ecosystem benefits that they can be providing for human settlements, as well as the implementation of strategies that ensure their sustainable exploitation and their conservation. The objective of this study was to analyze and compare two mature mangrove ecosystems in Paraíso, Tabasco, one of red mangrove ( $R$. mangle) and another of black mangrove (A. germinans) in their plant structure and nutritional characterization of the soil.

\section{MATERIALS AND METHODS}

Study area. The municipality of Paraíso is located in the region of the Grijalva River, in the sub-region known as Chontalpa in the state of Tabasco, at an average altitude of 10 meters above sea level. It has a territorial surface of 377.55 square kilometers (DomínguezDomínguez et al., 2011). The climate is warm-humid with abundant rainfall during the summer, with the months of May to August being the warmest, with temperatures that exceed 34 degrees centigrade (Palma-López et al., 2007). The study was performed in the locality called Nicolás Bravo 4th section, from this municipality, where the Tilapa Lagoon is located. The coordinates are $18^{\circ} 20^{\prime} 33^{\prime \prime}$ latitude North and $93^{\circ} 07^{\prime} 39^{\prime \prime}$ latitude West.

Experimental design and field sampling. Two plots of size $40 \times 20$ were established in R. mangle and of $30 \times 30 \mathrm{~m}^{2}$ in A. germinans, due to the location of each species. Plant sampling was done on September 3, 2019, with the transect method (Mostacedo \& Fredericksen, 2000); for this purpose, four transects of $15 \mathrm{~m}$ length by $10 \mathrm{~m}$ width in each mangrove plot were delimited with raffia palm thread. In each sampling unit an inventory of all the trees was conducted; of all the trees with basal diameter $\geq 2.5 \mathrm{~cm}$ the following data were recorded: diameter at breast height $(\mathrm{DBH})$, with the help of a diameter tape; height and percentage of the coverage with a Haga gun. In each transect the number of trees of smaller size was also counted, while in $R$. mangle they were measured $30 \mathrm{~cm}$ above the last aerial root (Corella-Justavino et al., 2004). The field information was systematized in the Excel 2016 software, where a database was generated, which was used to estimate the density of vegetation per hectare of each sampling unit. According to Velázquez-Pérez 
et al. (2019), seven diameter classes were established (2.5-4.9, 5-7.4, 7.5-9.9, 10-12.4, 12.5$14.9,15-19.9$ and $>20 \mathrm{~cm}$ ), in which the individuals sampled were placed, which allowed estimating the relative abundance of the species and the dynamics of emergence and disappearance of them in the ecosystem. The basal area $(B A)$ and the trunk volume $(V)$ were calculated through the following formulas (Mostacedo \& Fredericksen, 2000):

$$
B A=p(D 2 / 4)
$$

where: $p=3.141592$, and $D$ refers to the diameter at breast height $(\mathrm{DBH})$.

$$
V=B A^{*} h
$$

where $h$ refers to the total height of the trunk.

Soil sampling and analysis. The types of soils in each ecosystem were identified, based on the Global Soil Resource Referential Base (IUSS, 2015) and taking as reference the information from Palma-López et al. (2007). The soil samples were taken on days June 6, 2019 (dry season), and September 24, 2019 (rainy season). Samples were taken with Dutch type drill at depths of $0-30 \mathrm{~cm}$ and $30-50 \mathrm{~cm}$, each one of the two samples was made up of 15 sub-samples taken randomly in zig-zag for the two ecosystems. The chemical analysis of the soils performed were CIC (extraction with ammonium acetate), MOS (moist combustion Walkley and Black), total N (Semi-micro Kjeldahl, modified to include nitrites), $\mathrm{P}$ (Olsen), $\mathrm{PH}\left(\mathrm{CaCl}_{2}, 1: 2\right)$, exchangeable bases: (Na, K, $\mathrm{Ca}, \mathrm{Mg}$ ) (extraction with ammonium acetate $1.0 \mathrm{~N}$ to $\mathrm{pH} 7.0$ ) according to the methodology of NOM-021REGNAT-2000 (SEMARNAT, 2002); and lastly, humic and fulvic acids (KononovaBelchikova method).

\section{RESULTS AND DISCUSSION}

Soil characterization. The soils were classified as: Protosodic Stagnic Gleyic Solonchak (Clayic, Humic) for the ecosystem of black mangrove (Avicennia germinans) and Fluvic Sodic Stagnic Gleyic Solonchak (Clayic, Histic, Humic, Hypersalic) for the ecosystem of red mangrove (Rhizophora mangle) (IUSS, 2015). In both cases they are salinized soils where the processes of gleization and blockage of superficial water are dominant. In the ecosystem of $R$. mangle, the presence of salinity and sodicity is stronger, which coincides with what was reported by Palma-López et al. (2007) and Domínguez-Domínguez et al. (2011).

The two mangrove communities studied were made up only by the species that receive their name, and only in red mangrove was a single immature individual observed of the climbing plant Rhabdadenia biflora (Jacq.) Müll. Arg. The density of A. germinans was 1,633 individuals per hectare, higher than in R. mangle, whose density reached only 633. Domínguez-Domínguez et al. (2011) reported in the state of Tabasco that black mangrove was scarcer in number of individuals; in the characterization of the mangrove in two localities near the studied area, the same authors indicated a density lower than 308 trees per hectare for black mangrove and 279 for red mangrove. In contrast, Corella-Justavino $e t$ 
al. (2004) reported 1,109 and 774 trees of red and black mangrove per hectare, respectively, in Centla swamps. In Chiapas mangroves, the average density was 2,915 individuals ha ${ }^{-1}$, which were made up of young-mature $A$. germinans trees, located in salinized sites and with strong wood extraction of L. racemosa (Velázquez-Pérez et al., 2019).

Figure 1 shows the frequency of the diametric classes in the two ecosystems of study; in the case of $A$. germinans the distribution was characterized by presenting a higher concentration of individuals in the first category (2.5-4.9), with a tendency to decrease towards the last classes. Instead, $R$. mangle showed a more homogeneous distribution between the different classes, being slightly higher in the one of 7.5-9.9 cm, and the average DBH for those communities were 7.33 and $13.21 \mathrm{~cm}$, respectively. In this sense, CorellaJustavino et al. (2004) found the highest density in the first category in both species. In contrast, in the analysis of the mangrove structure in Mecoacán Lagoon, DomínguezDomínguez et al. (2011) mentioned that for Ejido Libertad 1st Section, red mangrove reflects an adequate incorporation of young individuals and a progressive decrease of these as they grow in age and diameter, while for black mangrove it presents an alarming scarcity of young individuals and trees that can reach $50 \mathrm{~cm}$ of diameter, which contrasts with the results of this study. However, the same study mentions that red mangrove has a very balanced diametric distribution in Ejido Campo Mecoacán, while black mangrove had an adequate young population for the size of its population, being evident that many black mangroves of older age have been respected.

Regarding the height of trees, Figure 2 shows their distribution in both communities studied, where a taller size is appreciated in red mangrove, whose average was $17.6 \mathrm{~m}$, while black mangrove barely reached $13.88 \mathrm{~m}$. Height is an indicator of the development of the structure of a stand, since a greater height is related with a higher DBH. Contrary to these data, in Centla Swamps the species that had the highest average height was $A$. germinans, followed by L. racemosa, the one of smallest size was R. mangle (Corella-Justavino et al., 2004). Likewise, Domínguez-Domínguez et al. (2011) reported ranges of 12 to 19 $\mathrm{m}$ for black mangrove in Tabasco, with values of 19 and $11 \mathrm{~m}$ for Ejidos Libertad 1st Section and Campo Mecoacán, sites close to the study area, respectively; and ranges of 9 to $16 \mathrm{~m}$ for red mangrove, and values of 15 and $16 \mathrm{~m}$ for the same ejidos. Sánchez et al.
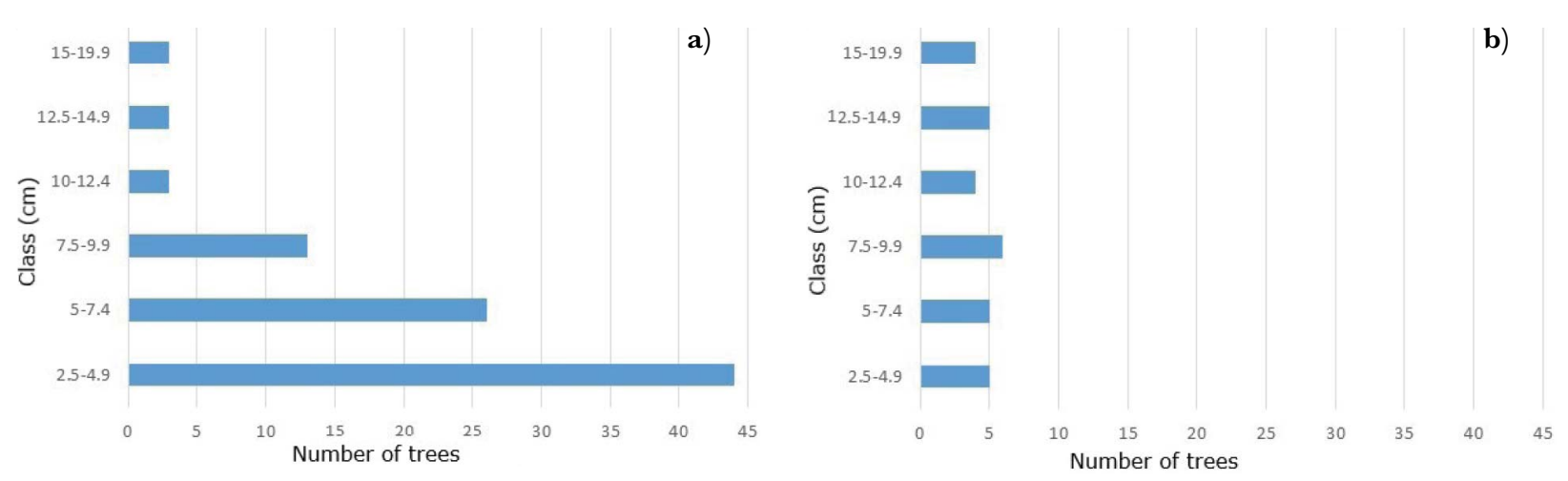

Figure 1. Distribution of trees by diameter class in two mature mangrove ecosystems: a) black mangrove, and b) red mangrove, both in Paraíso, Tabasco, Mexico. 


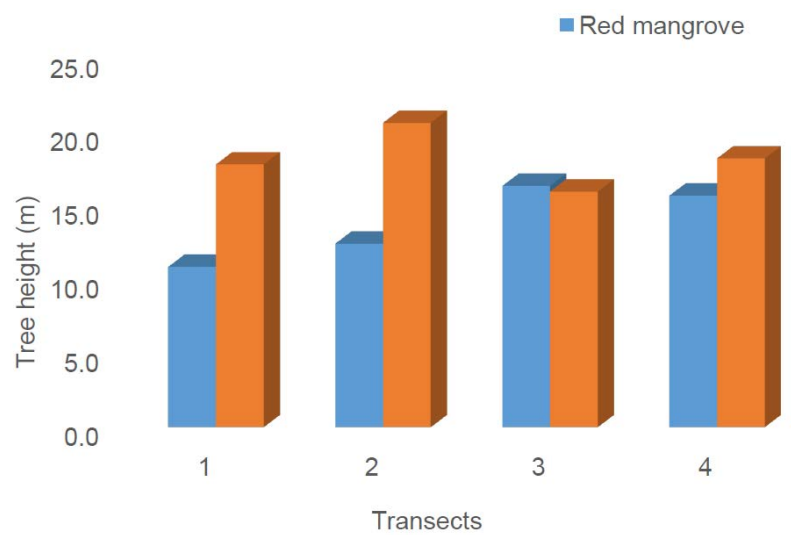

Figure 2. Tree height in sampled mangrove communities (two transects per season).

(2016) consider that the height in itself is not a limitation for their exploitation; however, it suggests that trees with mean heights lower than 10 meters are still not profitable for their exploitation, which is why respecting them and caring for their growth until they reach an adequate height is the suggestion.

Chemical properties of the soil associated to mangrove ecosystems. The average values of the chemical properties of soils at $0-50 \mathrm{~cm}$ depth in the ecosystems studied and in the two seasons (dry and rainy) are shown in Table 1. The $\mathrm{pH}$ showed values classified as neutral for black mangrove, and strong to moderately acid in red mangrove (SEMARNAT, 2002). The $\mathrm{pH}$ tends to be acid in tropical soils, and even more in those of mangrove (Sánchez-Arias et al., 2010); the anaerobic metabolism in the natural mangrove ecosystem occupied with flooded soils rich in sulfates, where its reduction is the dominant process, making the soil generally acid (Senior et al., 1982; Palma-López et al., 2007; Adame et al., 2018).

The percentages of organic matter $(\mathrm{OM})$ found were middle in black mangrove and high in red mangrove (SEMARNAT, 2002); this behavior seems to be due to the larger population and therefore the higher deposition of organic residues, with an increase of OM observed in both ecosystems during the rainy season. The seasonal variations of temperature, hours of sunshine, and level of flooding influence the fall of different parts of the plants, primarily leaves, and therefore in the increase of OM (Bernini et al., 2010; Alongi et al., 2014).

Table 1. Soil chemical properties of red mangrove (Rhizophora mangle) and black mangrove (Avicennia germinans) ecosystems spanning two seasons a year.

\begin{tabular}{|c|c|c|c|c|c|c|c|c|c|c|c|}
\hline \multirow{2}{*}{ Season } & \multirow{2}{*}{ Ecosystem } & \multirow{2}{*}{$\begin{array}{c}\text { pH }\left(\mathrm{H}_{2} \mathrm{O}\right) \\
\text { Rel. 1:2 }\end{array}$} & $\mathbf{O M}$ & $\mathbf{N}$ & \multirow{2}{*}{$\underset{\mathrm{mg} \mathrm{kg}}{\mathrm{P}}$} & $\mathbf{K}$ & Ca & $\mathrm{Mg}$ & GEC & HA & FA \\
\hline & & & & & & \multicolumn{4}{|c|}{$\mathrm{cmol}_{(\mathrm{c})} \mathrm{kg}^{-1}$} & \multicolumn{2}{|c|}{$\%$} \\
\hline \multirow{2}{*}{ Dry } & Black mangrove & 6.5 & 2.4 & 0.10 & 5.7 & 0.2 & 12.5 & 3.2 & 27.1 & 0.9 & 2.3 \\
\hline & Red mangrove & 4.9 & 4.6 & 0.17 & 8.2 & 0.3 & 14.9 & 5.3 & 32.3 & 1.3 & 2.57 \\
\hline \multirow{2}{*}{ Wet } & Black mangrove & 6.7 & 3.5 & 0.17 & 6.8 & 0.4 & 15.0 & 5.5 & 30.8 & 1.1 & 2.40 \\
\hline & Red mangrove & 5.2 & 8.1 & 0.35 & 10.7 & 0.5 & 15.3 & 8.0 & 33.3 & 2.1 & 3.42 \\
\hline
\end{tabular}

$\mathrm{OM}=$ Organic matter; $\mathrm{N}=$ nitrogen (Kjeldahl); $\mathrm{P}=$ Phosphorus (Olsen); $\mathrm{K}=$ Potassium; Ca=Calcium; Mg=Magnesium; CEC=Cation Exchange capacity; $\mathrm{AF}=$ Fulvic acids $\mathrm{HA}=$ Humic acids. 
The $\mathrm{N}$ contents in black mangrove were middle and in red mangrove high (Table 1), being higher in the rainy season, and these values have correspondence with the levels of OM. Red mangrove (R. mangle) remains flooded longer during the rainy season and has higher OM deposition (Sánchez-Junco et al., 2011; Fernandes et al., 2012, Romero et al., 2012).

Phosphorus presented middle values in the two mangrove ecosystems and in the two seasons, dry and rainy (Table 1); however, the highest average values were found in red mangrove $\left(9.5 \mathrm{mg} \mathrm{kg}^{-1}\right.$ ) (SEMARNAT, 2002). Phosphorus is an element that in tree agroecosystems tends to present middle values, and this is related to the property that trees have to extract this element from great depths in the soil (Middleton \& Mckee, 2001; Sánchez et al., 2016).

The exchangeable bases presented variations that seem to be influenced by the season, showing an important increase in $\mathrm{K}$ (40\% in the two ecosystems) and $\mathrm{Mg}$ in its content for the rainy season (58\% black mangrove and $66 \%$ red mangrove), and also in Ca for that same period, showing a higher concentration although less pronounced. The contents of $\mathrm{K}$ in the two ecosystems during the dry season were very low to low, while during the rainy season they were middle to high. And in seasons they were very low to low, contrary case to $\mathrm{Mg}$ and $\mathrm{Ca}$, which had high contents (SEMARNAT, 2002).

The cationic exchange capacity (Table 1) in the soils studied was high (SEMARNAT, 2002). The presence of the mangrove species, the type of soil, the constant contributions of residues from deposition, as well as those related to plant coverage, favor soil fertility (Dinesh et al., 2004). In this regard, Bautista-Cruz et al. (2004) mention that the cationic exchange capacity increases when there is high presence of organic matter and the CEC presents higher values, which vary from 25 to $40 \mathrm{Cmol} \mathrm{kg}^{-1}$.

The contents of humic and fulvic acids (Table 1) in the agroecosystems studied were high. These are part of the complex organic matter system of the soil (SOM), they are product of the partial decomposition that results from the microbiological and chemical transformations, and present a high buffering capacity (Singh et al., 2005; Kida \& Fujitake, 2020).

\section{CONGLUSION}

The soil from the two mangrove ecosystems corresponded to saline soils dominated by the gleization processes, stagnation, and in both sites it was classified as Solonchaks. In diametric aspects, the species of $R$. mangle presented values with higher $\mathrm{DBH}$, height and plant coverage. The analyses generated indicate that the vegetation and the type of species influence the nutritional results of the soil, since each fulfills a specific function that provides good development of the mangrove species, and they also influence the seasons of the year in each ecosystem, and the greatest development of $R$. mangle when comparing its dasometry with $A$. germinans.

\section{REFERENGES}

Adame, M.F., Brown, C., Bejarano, M., Silveira, J., Ezcurra, P., \& Kauffman, J. (2018). The undervalued contribution of mangrove protection in Mexico to carbon emission targets. Conservation Letters, 11: 1-9. 
Alongi, D.M. (2014). Carbon cycling and storage in mangrove forests. Annual Review of Marine Science, 6: 195-219.

Bautista-Cruz A., Etchevers-Barra, J., Del Castillo, R.F., \& Gutiérrez, C. (2004). La calidad del suelo y sus indicadores. Ecosistemas, 13 (2): 90-97.

Bernini, E., Da Silva, M.A.B., Do Carmo, T.M.S., Cuzzuol, G.R.F. (2010). Spatial and temporal variation of the nutrients in the sediment and leaves of two Brazilian mangrove species and their role in the retention of environmental heavy metals. Brazilian Journal of Plant Physiology, 22(3): 177-187.

Corella-Justavino, F., Valdez-Hernández, J.I., Cetina-Alcalá, V.M., González-Cossío, F.V., Trinidad-Santos, A., \& Aguirre-Rivera, J.R. (2004). Estructura forestal de un bosque de mangles en el noreste del estado de Tabasco, México. Ciencia Forestal en México 26(90): 73-102.

Dinesh, R., Chaudhuri, S.G., Ganeshamurthy, A.N., \& Pramanik, S.C. (2004). Biochemical properties of soils of undisturbed and disturbed mangrove forests of South Adaman, India. Wetlands Ecology and Management, 12: 309-320.

Domínguez-Domínguez, M., Zavala-Cruz, J., \& Martínez-Zurimendi, P. (2011). Manejo forestal sustentable de los manglares de Tabasco. Villahermosa: SERNAPAM-Colegio de Postgraduados.

Domínguez-Domínguez, M., Zavala-Cruz, J., Galmiche-Tejeda, A., Martínez-Zurimendi, P., SolanaVillanueva, N., \& Pereyra-Alférez, J. (2009). Estudio para el manejo sustentable de los manglares de la zona costera del estado de Tabasco. Villahermosa: SERNAPAM-Colegio de Postgraduados.

FAO. (2007). The world's mangroves 1980-2005. V. 153. Roma: Food and Agriculture Organization of the United Nations.

Fernandes, S.O., Michotey, V.D., Guasco, S., Bonin, P.C., \& Bharathi, P.A. (2012). Denitrification previals over ananmox in tropical magroves sediments in Goa, India. Marine Environmental Research, 74: 9-19.

IUSS Working Group WRB, 2015. Base referencial mundial del recurso suelo 2014, Actualización 2015. Sistema internacional de clasificación de suelos para la nomenclatura de suelos y la creación de leyendas de mapas de suelos. Informes sobre recursos mundiales de suelos 106. Roma: Food and Agriculture Organization of the United Nations.

Kida, M., \& Fujitake, N. (2020). Organic carbon stabilization mechanisms in mangrove soils: a review. Forests, 11(9): 981.

Middleton, B.A., \& Mckee, K.L. (2001). Degradation of mangrove tissues and implications for peat formation in Belizean island forests. Journal of Ecology, 89: 818-828.

Mostacedo, B., \& Fredericksen, T.S. (2000). Manual de métodos básicos de muestreo y análisis en ecología vegetal. La Paz: BOLFOR.

Palma-López, D.J., Cisneros-Domínguez., J., Moreno-Cáliz, E., \& Rincón-Ramírez, J.A. (2007). Suelos de Tabasco: su uso y manejo sustentable. Villahermosa: FUPROTAB-Colegio de Postgraduados.

Pérez-Sánchez, E., Muir, J., \& Ross, L. (2002). Coastal aquaculture and sustainable livelihoods in Mecoacán, Tabasco, México. Universidad y Ciencia, 18: 42-52.

Romero, I.C., Jacobson, M., Fuhrman, J.A., Fogel, M., \& Capone, D.G. (2012). Long-term nitrogen and phosphorus fertilization efects on $\mathrm{N}_{2}$ fixaxcion rates and nifH gene community patterns in mangrove sediments. Marine Ecology 33: 117-127.

Sánchez, L.V., Obrador-Olán, J.J., García-López., E., \& Carrillo-Ávila, E. (2016). Densidad de longitud de raíces de Acacia mangium Will en un suelo de sabana. Agro Productividad, 9(2): 3-11.

Sánchez-Arias, L.E., Paolini, J., \& Rodríguez, J.P. (2010). Dinámica de las propiedades del suelo en bosques de Rhizophora mangle L. (Rhizophoraceae) en Isla de Margarita, Venezuela. Revista de Biología Tropical, 58(2): 547-564.

Sánchez-Junco, R.G., Damián-Hernández, D.L., Cerón-Bretón, R.M., Cerón-Bretón, J.G., DamiánHernández, D.L., Guerra-Santos, J.J., Rangel-Marrón, M., Sánchez-Junco, R.C., \& Zavala-Loría, J.C. (2011). Determinación del carbono almacenado en suelo con asociación de mangle rojo en Nuevo Campechito, Campeche. Unacar Tecnociencia, 5(1): 1-7.

SEMARNAT. (2002). Norma Oficial Mexicana NOM-059-ECOL-2001, Protección ambiental - Especies nativas de México de flora y fauna silvestre - Categorías de riesgo y especificaciones para su inclusión, exclusión o cambio - Lista de especies en riesgo. Ciudad de México: Diario Oficial de la Federación-Secretaria de Medio Ambiente y Recursos Naturales.

Senior, E., Lindstrom, E. B., Banat, I. M., \& Nedwell, D.B. (1982). Sulfate reduction and methanogenesis in the sediment of a Saltmarsh on the East Coast of the United Kingdom. Applied Environmental Microbiology, 43: 987-996.

Singh G., Ramanathan A.L., \& Prasad M.B.K. (2005). Nutrient Cycling in the mangrove environment: a brief review. International Journal of Ecology and Environmental Sciences 24-31: 231-244. 
Valderrama-Landeros L.H., Rodríguez-Zúñiga, M.T., \& Troche-Souza, G. (2017). Manglares de México: actualización y exploración de los datos del sistema de monitoreo 1970/1980-2015. Ciudad de México: CONABIO.

Velázquez-Pérez, C., Tovilla-Hernández, C., Romero-Berny, E.I., \& Jesús-Navarrete, A. (2019). Estructura del manglar y su influencia en el almacén de carbono en la Reserva La Encrucijada, Chiapas, México. Madera y Bosques 25(3): 2531885 